\title{
Changes in lake-sediment stratigraphy associated with late glacial climate change: examples from western Nova Scotia
}

\author{
Ian S. Spooner \\ Department of Geology, Acadia University, Wolfville, Nova Scotia B0P 1X0, Canada
}

\author{
Date Received June 3, 1998 \\ Date Accepted December 31, 1998
}

\begin{abstract}
An investigation of lake-sediment stratigraphy in western Nova Scotia has focused on determining the environmental response to late-glacial climate change. Sediment records from five headwater lakes were recovered and sediment stratigraphy from four of the lakes was used to reconstruct late-glacial environments for this region.

Results from Sand Lake and Canoran Lake (South Mountain) indicate that the South Mountain was deglaciated by about 11,500 B.P. The North Mountain was deglaciated slightly earlier. All cores contained till (unit 1) which was overlain by a fine-grained diamicton (unit 2) that was deposited after ice had receded. A gyttja with varying mineral sediment concentrations (unit 3) overlies unit 2 . Unit 2 is interpreted as sediment that was transferred to the basin as the basin and catchment stabilized. The North Mountain sites are characterized by lack of a Younger Dryas-equivalent loss-on-ignition or mineral oscillation. The South Mountain sites both contain a thin $(2 \mathrm{~cm})$ Younger Dryasequivalent mineral horizon (unit 4) bounded above and below by sandy gyttja (units 3 and 5). Image and grain size analysis of units 3,4 and 5 indicate that these units differ primarily in their amounts of fine silt and clay, as maximum grain size is similar in each unit. This result indicates that changes in sediment transfer mechanisms in response to climate change were subtle. The formation of unit 4 (YDimh) was primarily a consequence of intrabasin sediment transfer and reduced productivity; an increase in the extent and/or duration of lake ice cover may have been an important factor. The catchment response to Younger Dryas climate change in western Nova Scotia was probably subdued. Though aufeis and perennial snow cover may have existed at some sites, the presence of Younger Dryasequivalent glacial ice in western Nova Scotia is unlikely.
\end{abstract}

Une étude stratigraphique des sédiments lacustres dans l'ouest de la Nouvelle-Écosse s'est attachée à déterminer la réaction de l'environnement au changement climatique tardiglaciaire. On a récupéré des échantillons de sédiments de cinq lacs d'amont et on a utilisé les données stratigraphiques des sédiments de quatre des lacs pour reconstruire les environnements tardiglaciaires de cette région.

Les résultats obtenus du lac Sand et du lac Canoran (mont South) révèlent que la déglaciation du mont South est survenue vers 11500 avant le présent. La déglaciation du mont North s'est produite légèrement plus tôt. Toutes les carottes contenaient du till (unité 1) recouvert de diamicton à grain fin (unité 2) qui s'était déposé après la disparition de la glace. Un gyttja renfermant des concentrations de sédiments minéraux variables (unité 3 ) recouvre l'unité 2. Cette dernière est interprétée comme le résultat d'un transfert de sédiments dans le bassin sédimentaire au moment où le bassin sédimentaire et le bassin hydrographique se sont stabilisés. Les points du mont North se caractérisent par une absence d'oscillation minérale ou de perte au feu équivalente au Dryas récent. Les points du mont South renferment tous deux une mince couche $(2 \mathrm{~cm})$ d'horizon minéral équivalent au Dryas récent (unité 4) délimitée audessus et au-dessous par un gyttja sableux. Les images et l'analyse de la granulométrie des unités 3,4 et 5 révèlent que ces unités sont différentes, principalement en ce qui concerne leurs teneurs en argile et en silt fins, car la taille maximale des grains est semblable dans chaque unité. Ce résultat témoigne du fait que les changements dans les mécanismes de transfert des sédiments consécutifs au changement climatique ont été subtils. La formation de l'unité 4 (YDimh) a principalement été provoquée par un transfert de sédiments à l'intérieur du bassin et une productivité réduite; l'augmentation de l'étendue ou de la durée de la couverture de glace du lac a peut-être constitué un facteur déterminant. La réaction du bassin hydrographique au changement climatique du Dryas récent dans l'ouest de la Nouvelle-Écosse a probablement été estompée. Même si un aufeis et un tapis de neige pérenne ont pu exister en certains endroits, la présence de glace de l'ère glaciaire équivalente au Dryas récent dans l'ouest de la Nouvelle-Écosse est improbable.

Traduit par la rédaction

\section{INTRODUCTION}

Research on late-glacial environmental change in Nova Scotia by Mott (1985, 1994), Mott et al. (1986), Stea and Mott (1989, 1998), Wilson et al. (1992), Mott and Stea (1993), King (1996, 1993), Stea et al. (1996), Levesque et al. (1997), and various other authors has resulted in a detailed understand- ing of late-glacial paleoenvironments. Both terrestrial and lacustrine sites have yielded sedimentological and biotic data that have been used to reconstruct the timing of deglaciation and regional late-glacial climate conditions, with particular focus on the Younger Dryas (YD) event. The Younger Dryas event has been recognized as perhaps the best available record of abrupt climate change. In Nova Scotia the physical record of 
the Younger Dryas event is particularly well preserved, and most research has focused on resolving the timing, magnitude, and extent of the change in climate.

This study focuses on describing in detail the late-glacial sediment stratigraphy of four headwater lakes in western Nova Scotia in an attempt to understand how sediment transfer processes changed in response to Younger Dryas cooling. Mott and Stea (1993) have indicated that landscape destabilization was one consequence of Younger Dryas cooling which resulted in the formation of a mineral oscillation in many lake basins. Stea and Mott (1998) and others have noted that, although the nature and intensity of changes in late-glacial sediment influx was varied, some patterns existed. In southern Nova Scotia the distribution of lakes that contain a mineral oscillation indicated either by a decrease in total organic carbon (T.O.C.) or as a Younger Dryas inorganic marker horizon (YDimh) (Stea and Mott, 1998) is sporadic; many lakes contain no sedimentological evidence of Younger Dryas climate change. In lakes in northern Nova Scotia a YDimh appears to be more common.

The equivocal distribution of sedimentological evidence of Younger Dryas climate change has not been adequately explained. Indeed, very little research has focused on the sedimentology of the YDimh itself. Less is known about the nature of the glacial (usually till) to lacustrine sediment (gyttja) transition. There is uncertainty as to which internal (basin) and external (catchment) physical, chemical and/or biological driving forces were responsible for changes in late-glacial sediment influx. Headwater lakes were chosen for this study as limited throughflow increases sediment preservation potential. As well, the nature of the response to climate change (landscape instability, productivity fluctuations, increased meltwater influx, intrabasin instability, etc.) might best be discerned in this setting. The sites chosen for this study form a northwest to southeast transect across western Nova Scotia (Fig. 1). This region was chosen because Mott and Stea (1993) demonstrated that the lake record of late-glacial climate change was highly variable in this region. As well, King (1996) and Miller (1996) indicated that glaciers may have existed on South Mountain during Younger Dryas time. This study will demonstrate that insight into both local and regional late-glacial environmental change can be gained from a detailed examination of the lake sediments deposited during this period.

\section{LOCATION AND REGIONAL GEOLOGY}

Five lakes were cored during this study (Fig. 1). Ramsey Lake, Sandy Lake, and Youngs Lake are located on North Mountain, a 200-m-high cuesta located on the southern shore of the Bay of Fundy. The cores from Ramsey Lake and Sandy Lake are stratigraphically similar, and hence only the cores from Sandy Lake and Youngs Lake are included in this paper. The other two lakes are located on South Mountain, a 250-mhigh highland formed over resistant Devonian intrusive rocks that forms much of western Nova Scotia. Sand Lake is on the apex of South Mountain, and Canoran Lake (100 m a.s.1.) is situated on the southern edge within $30 \mathrm{~km}$ of the Atlantic Ocean (Fig. 1). The Annapolis Valley is located between the two highlands and consists of a glacially deepened valley that overlies poorly indurated Mesozoic sedimentary rocks.

Models for Late Wisconsinan glaciation in western Nova Scotia are complex. King (1993, 1996), Stea et al. (1996), Stea and Mott (1998), and others have shown that a series of glacial advances from shifting ice centres and the development of offshore ice divides resulted in complex striation records and the presence of stacked till sheets. These data have been used to reconstruct at least four distinct ice flow phases, each with at least one recognizable till sheet (Stea et al., 1992). During the final stages of deglaciation remnant ice caps developed in highland areas; some of these ice caps may have been rejuvenated during Younger Dryas time (Stea and Mott, 1989; Miller, 1996; King, 1996). Railton (1973), Mott (1985), Miller (1996), and others reconstructed late-glacial environmental change using a wide variety of data obtained from lake and terrestrial sediments. The basal ages of lake cores have been used to reconstruct the timing of deglaciation, and pollen, diatom, and macrofossil records have been used to reconstruct regional climate conditions. Stea and Mott (1998) described Younger Dryas-equivalent sediment input in many lakes in Nova Scotia and noted a general south to north increase in both the thickness and the mineral content of the YDimh. Cwynar and Levesque (1995) described Younger Dryasequivalent gravel and sand deposits in lakes in western New Brunswick and Maine but did not elaborate on the depositional process. Doner (1995) noted a distinct increase in sandsized particles over the Younger Dryas interval in cores from Maine.

Terrestrial records of both deglaciation and Younger Dryas cooling and reinvigoration of ice caps have also been recognized in mainland Nova Scotia (Mott and Stea, 1993). A wide variety of sediments has been found overlying peat, and in central and northeastem Nova Scotia a Younger Dryas-equivalent ice advance appears likely (Mott and Stea, 1993). The distribution of glacial outwash and deltaic, lacustrine, and marine deposits have all been used to reconstruct paleogeography during deglaciation (Stea and Mott, 1989; King, 1993, 1996; Stea et al., 1996; Broster and MacDougall, 1997).

\section{MeThoD}

Core sampling was carried out through lake ice during the winters of 1995 and 1996. In all lakes a minimum of three cores were retrieved. Sampling locations were chosen with the aid of Nova Scotia Department of Fisheries bathymetry maps. A King 1570 sonar unit was used to produce sub-bottom profiles of the lake basins. In most cases a variety of site locations within each lake basin were sampled. Complex subbottom stratigraphy was encountered at all sites. Where possible, basin-central sites that showed near-horizontal sediment contacts were chosen, because sediment creep on local basin margins or on the margins of bedrock or till knobs can deform or produce gaps in core stratigraphy (Cole, 1994). A portable percussion coring system (Reasoner, 1993) was used to obtain several cores, $7.5 \mathrm{~cm}$ in diameter. The core barrels are $3 \mathrm{~m}$ in length and can be coupled. Continuous sediment cores were obtained at each site. These cores were recovered 


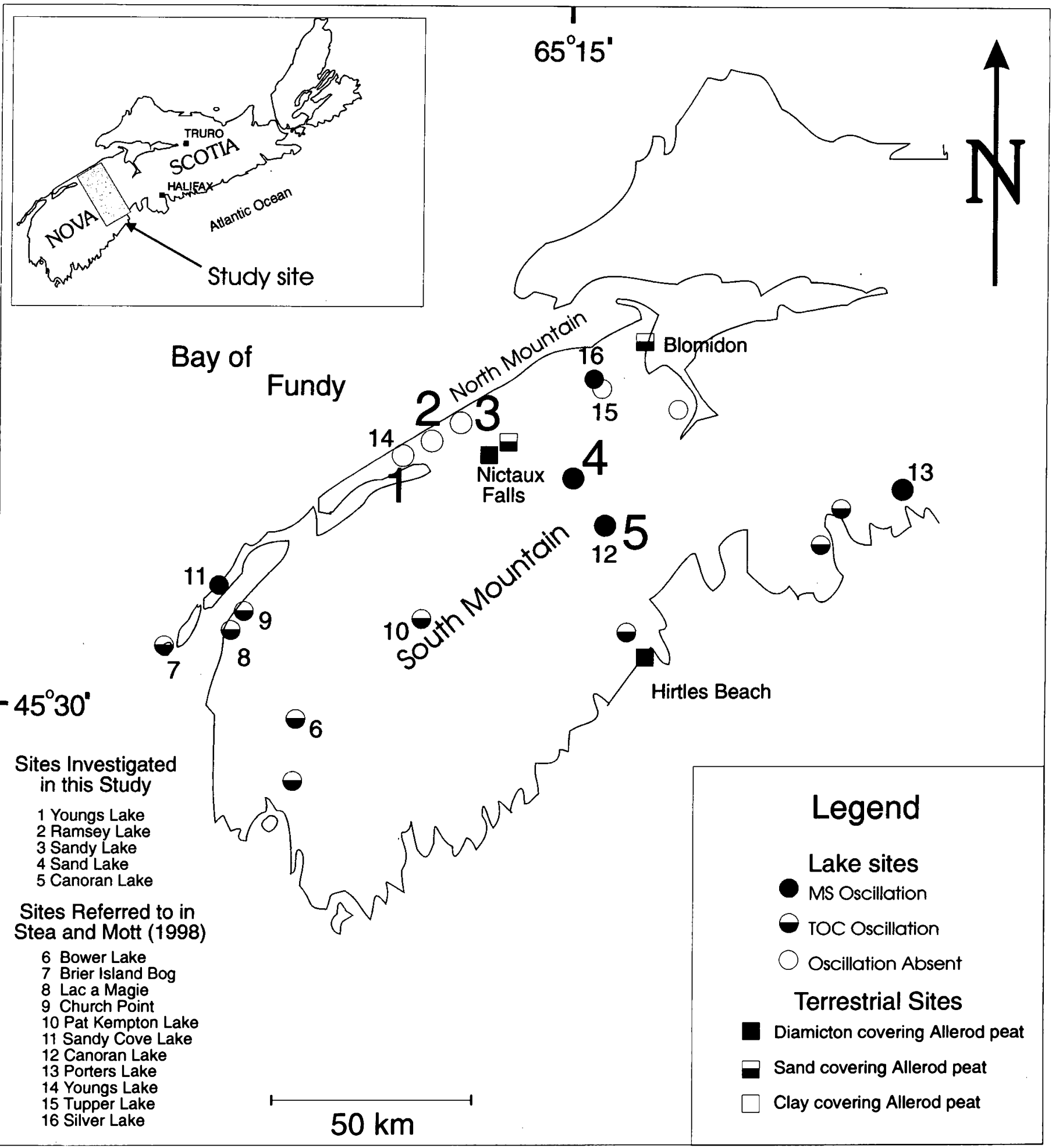

Fig. 1. Location of lake and terrestrial sites cored in this study and by other authors. The lakes included in this study form a northwest - southeast transect across western Nova Scotia.

when penetration ceased, and the average length of consolidated lake sediment obtained was about $2.5 \mathrm{~m}$. All cores were frozen and split with a table saw equipped with a ceramic blade. The cores from each specific lake were compared to each other and dissimilarities were noted. The cores in which unit contacts and internal features were best preserved were chosen for detailed study. Only the lower section of each core was described in detail as the nature of the middle and late Holocene sediment stratigraphy was not the focus of this study. Loss-on-ignition (L.O.I.) analysis, which gives an indication of the relative organic carbon content of the sediment, was performed. Those cores that exhibited a mineral oscillation were analyzed for inorganic grain size distribution using a Fritsch Laser Particle Sizer Analysette 22-E. This sys- 
tem has a range of 0.16 to $630 \mu \mathrm{m}$ and produces grain size results in volumetric percentages. Thin section analysis was carried out on select intervals of the cores and thin sections were prepared by impregnating core samples. Image analysis was performed on thin sections using thin section images and the Image $\mathrm{Tool}^{\circ}$ image analysis system. This program was used to determine the relative abundances of quartz clasts through the application of image enhancement and classification procedures. The clast grain size resolved was coarse silt sized $(0.025 \mathrm{~mm})$ and greater, and was limited by the pixel size of the thin section images acquired. Average and maximum grain size of the sand-sized fraction $(0.05-2.0 \mathrm{~mm})$ were computed. The presence and relative abundance of both diatoms and pollen grains were noted. These data were used primarily as a coarse indication of either lake or terrestrial productivity; no attempt was made to describe or count either indicator.

Chronological control for select cores was provided by beta decay and AMS radiocarbon (Table 1). Macrofossils were recovered by sieving ( $250 \mu \mathrm{m}$ mesh screen) 2 -cm-long segments of the core that had been previously sub-sampled for sediment analysis. Where present, plant macrofossils were identified using modern reference specimens. Many of the cores contain a paucity of macrofossils and plant detritus, precluding the use of the AMS radiocarbon technique. Canoran Lake (South Mountain) was previously investigated by Railton (1973) and Stea and Mott (1998) and the ages published in those papers were considered in this report.

\section{Results}

\section{Site and core descriptions: North Mountain sites}

\section{General description}

The North Mountain lake sites (Fig. 1) are all located on the southern side of the North Mountain cuesta (maximum elevation $238 \mathrm{~m}$ ), a basalt ridge that dips to the north. Soil cover is generally less than $10 \mathrm{~m}$ and regional drainage follows the structural dip to the north. Both sites are located within $10 \mathrm{~km}$ of the coastline. The lakes are fairly shallow $(<10$ m maximum depth) and are spring fed (Nova Scotia Department of Fisheries, 1995). At both Sandy Lake and Youngs Lake, sub-bottom stratigraphy is characterized by bedrock/ till undulations and variations in gyttja thickness of up to $2 \mathrm{~m}$ within the lake basin.

\section{Sandy Lake}

Sandy lake is located at $44^{\circ} 56^{\prime} \mathrm{N}, 65^{\circ} 14^{\prime} \mathrm{W}$ in Annapolis County (Fig. 1). The lake is $800 \mathrm{~m}$ long and $250 \mathrm{~m}$ wide, and has a small outlet at its northeastern end. Average depth is 4 $\mathrm{m}$ with a maximum depth of $9.8 \mathrm{~m}$. The lake does not have a well developed inlet and is fed primarily by groundwater springs with some surface runoff contribution. The lake is classified as meso-oligotrophic and lake waters have a pH of 6.5. Relief within the lake catchment is $50 \mathrm{~m}$ and lakeside gradients are moderate. Three cores were extracted from Sandy Lake; all have similar stratigraphy.

Sandy Lake core \#2 is $180 \mathrm{~cm}$ long and consists of 3 distinct units (Fig. 2). The basal unit (unit 1; 180-118 cm; L.O.I. 4\%) consists of a coarse-grained reddish-brown diamicton with angular cobble clasts suspended in a clay matrix; many of the clasts are striated and some have exotic compositions. This unit grades upward into a fine-grained, matrix-supported, clay-dominated diamicton (unit $2 ; 118-90 \mathrm{~cm} ;$ L.O.I. $9.5 \%$ ) that contains sporadic angular medium-grained sand to mediumgrained gravel clasts (13\%). Scattered diatoms were noted within this unit. The fine-grained diamicton is abruptly overlain by a black gyttja (unit 3 ) which continues uninterrupted to the top of the core. L.O.I. for the gyttja averages about $35 \%$ and sporadic, very fine- to fine-grained angular sand grains $(<1 \%)$ were noted within this unit. The gyttja contains abundant fossil pollen and diatoms as well as plant macrofossils. An AMS radiocarbon age of $11,760 \pm 240$ years B.P. was obtained on a twig recovered at the base of unit 3 (Fig. 2, Table 1). A bulk beta decay radiocarbon age of $7330 \pm 200$ years B.P. was obtained near the base of unit 3 in Sandy Lake core \#3.

Table 1. Dates referred to in this study. Note that the date for Canoran Lake was obtained by Railton (1973).

\begin{tabular}{|c|c|c|c|c|}
\hline Site & $\begin{array}{l}\text { Height } \\
\text { (from base } \\
\text { of core) }\end{array}$ & Age (yr B.P.)* & $\begin{array}{l}\text { Laboratory } \\
\text { Number }\end{array}$ & $\begin{array}{l}\text { Material } \\
\text { Dated }\end{array}$ \\
\hline Sand Lake, NS, core \#2 & $40 \mathrm{~cm}$ & $10,296 \pm 130($ AMS $)$ & TO-6739 & plant fragments \\
\hline Sand Lake, NS, core \#1 & $32-35 \mathrm{~cm}$ & $8530 \pm 620(\mathrm{BET})$ & GX-22224 & bulk sediment \\
\hline Sandy Lake, NS, core \#2 & $90 \mathrm{~cm}$ & $11,760 \pm 240(\mathrm{AMS})$ & TO-6108 & twig \\
\hline Sandy Lake, NS, core \#3 & $79-80 \mathrm{~cm}$ & $7330 \pm 200(\mathrm{BET})$ & GX-22225 & bulk sediment \\
\hline Canoran Lake, NS & $\mathbf{n} / \mathbf{a}$ & $11,700 \pm 160(\mathrm{BET})$ & GSC-1486 & bulk sediment \\
\hline
\end{tabular}

Radiocarbon dates for sites referred to in this paper.

*AMS denotes Accelerator Mass Spectrometer technique, BET denotes beta decay technique. 


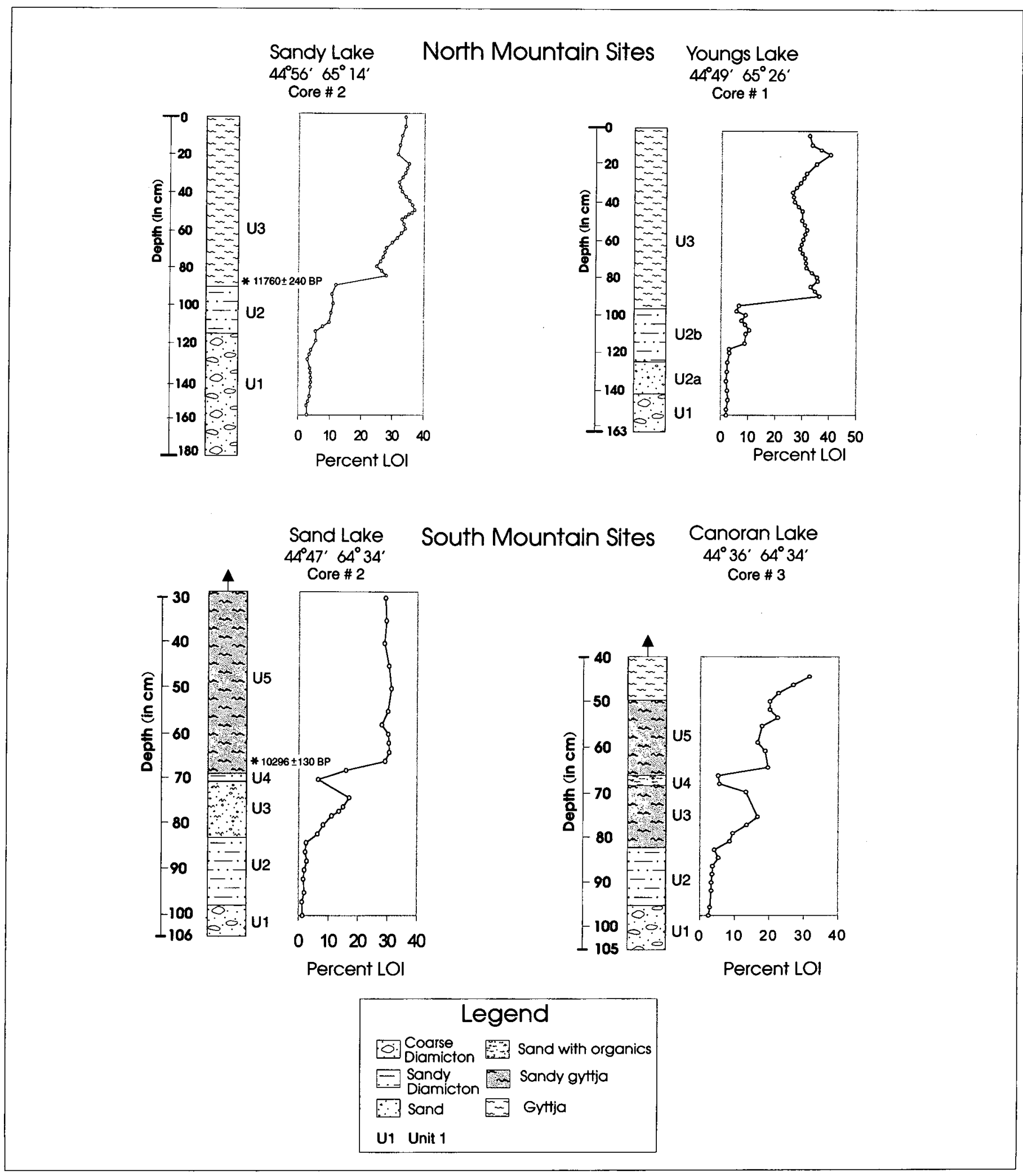

Fig. 2. Stratigraphy and Loss-on-Ignition (L.O.I.) data for four of the lake sediment cores described in this study. Five distinct units were observed primarily on the basis of grain size, texture, and volume of the clastic component.

\section{Youngs Lake}

Youngs Lake is located at $44^{\circ} 49^{\prime} \mathrm{N}, 65^{\circ} 26^{\prime} \mathrm{W}$ in Annapolis County (Fig. 1). The lake is $300 \mathrm{~m}$ long and $175 \mathrm{~m}$ wide, and does not have a well developed inlet or outlet. The lake is fed primarily by groundwater (Nova Scotia Department of Fisheries, 1995). The average lake depth is $1.5 \mathrm{~m}$ with a maximum depth of about $3.5 \mathrm{~m}$. Three cores were extracted from Youngs Lake; all have similar stratigraphy. The water quality in Youngs Lake is mesotrophic and the present $\mathrm{pH}$ of the lake water is 
6.4. The catchment relief is less than $25 \mathrm{~m}$ and the lakeside gradients are low to moderate.

Youngs Lake core \#1 is $163 \mathrm{~cm}$ long and contains 4 distinct units (Fig. 2). The basal unit (unit 1 ) is similar to that observed in the Sandy Lake core and consists of a reddish brown compact diamicton (163-142 cm; L.O.I. 3\%) with striated clasts, some of which have exotic compositions. This sediment is in sharp contact with a $17 \mathrm{~cm}$ thick unit (unit 2a; $142-125 \mathrm{~cm}$; L.O.I. $3 \%$ ) that contains a variety of thin strata including a sorted angular gravel layer $(4 \mathrm{~cm})$ followed by a compact diamicton $(3 \mathrm{~cm})$ which is overlain by well-sorted dark brown sand $(10 \mathrm{~cm})$. Unit $2 \mathrm{a}$ is in gradational contact with a reddish-brown clay diamicton (unit $2 \mathrm{~b} ; 125-95 \mathrm{~cm}$; L.O.I. $7 \%$ ) that contains medium-grained sand ( $16 \%$ ) to fine-grained angular gravel clasts. The clay diamicton is overlain by organic-rich gyttja similar to that observed in the Sandy Lake core (Unit 3, $95 \mathrm{~cm}$ - top of core, L.O.I. 35\%). The gyttja changes in colour from dark brown to black over $10 \mathrm{~cm}$ but no trend was observed in L.O.I. values.

\section{Site and core descriptions: South Mountain sites}

\section{General description}

South Mountain is the common name for a regional high (maximum elevation $282 \mathrm{~m}$ ) that exists over the South Mountain Batholith, a large resistant granitic pluton. Quaternary sediment is generally thin and bouldery except in areas where drumlins are well developed; surface drainage is generally disorganized. Both Sand Lake and Canoran Lake are located in drumlinized terrain. At both sites the bathymetry and stratigraphy are complex (Fig. 3). Both lakes contain at least one prominent sill, leading to the development of local basins within the lake. Gyttja thickness is highly variable and is typically greatest at the intrabasin margins. Large boulders may be present at the base of the gyttja and accentuate relief at this contact.

\section{Sand Lake}

Sand Lake is located at $44^{\circ} 47^{\prime} \mathrm{N}, 64^{\circ} 34^{\prime} \mathrm{W}$ in Lunenburg County (Fig. 1). The lake is about $750 \mathrm{~m}$ long and $400 \mathrm{~m}$ wide, and has a small outlet at its southern margin. The average lake depth is $3 \mathrm{~m}$ with a maximum depth of $10 \mathrm{~m}$. The lake is fed primarily by surface runoff (Nova Scotia Department of Fisheries, 1995). Sand Lake is mesotrophic and present lake $\mathrm{pH}$ is 6.8. Stratigraphy is similar in the four cores collected; however, core \#2 contains the longest sediment sample and it is described in detail. Relief within the lake catchment is less than $25 \mathrm{~m}$ and lakeside gradients are low.

The section of core \#2 studied is $106 \mathrm{~cm}$ long and consists of 5 distinct sedimentary units (Fig. 2). The basal unit (unit 1, 106-98 cm) consists of a matrix-supported reddish brown clay diamicton with abundant gravel clasts; L.O.I. for this unit averaged $2 \%$. Unit 1 grades upward into a fine-grained diamicton (unit 2, 98-83 cm, L.O.I. 2.5\%) with abundant coarsegrained sand to medium-grained angular gravel clasts (15\%); these clasts fine upward. Unit 2 is in sharp contact with unit 3
$(83-71 \mathrm{~cm})$ which is composed of dark brown sediment in which the L.O.I. increases upward from 7 to $15 \%$. This sediment contains abundant fine- to medium-grained angular sand clasts (7\%) which exhibit an up-core increase in abundance but not in grain size. Abundant diatoms and pollen grains were observed in this unit. Unit $4(71-69 \mathrm{~cm})$ is a reddish brown claysilt layer (L.O.I. 6\%) that contains angular fine- to mediumgrained sand clasts ( $9 \%$, Fig. 4). Scattered fine gravel clasts were observed. This unit contains diatoms and rare pollen grains. The contact with underlying unit 3 is sharp but convoluted; the contact with overlying unit 5 is sharp (Fig. 5). Unit 5 sediment ( $69 \mathrm{~cm}$ - top of core) consists of dark brown to black organic-rich gyttja (L.O.I. 31\%). Fine- to mediumgrained angular sand clasts (5\%) are common in the lower parts of this unit but become increasingly rare up-core. This unit contains abundant diatoms, pollen grains, and plant macrofossils. Volumetric grain size analysis of the minus $630 \mu \mathrm{m}$ clastic sediment (Fig. 6) indicates that sand-sized clasts are most numerous in units $3(40.3 \%)$ and $5(29.3 \%)$, with lower concentrations in unit $2(2.9 \%)$ and unit $4(14 \%)$. An AMS radiocarbon age of $10,296 \pm 130$ years B.P. on a terrestrial plant fragment was obtained at $66 \mathrm{~cm}$ from the top of the core. A bulk sediment beta decay radiocarbon age of $8530 \pm 620$ years B.P. was obtained near the base of unit 5 in Sand Lake core \#1 (Table 1).

\section{Canoran Lake}

Canoran Lake is located at $44^{\circ} 36^{\prime} \mathrm{N}, 64^{\circ} 34^{\prime} \mathrm{W}$ in Lunenburg County (Fig. 1). This lake is roughly circular and has an average diameter of $400 \mathrm{~m}$. The lake depth averages about $3 \mathrm{~m}$ and the maximum depth is $10 \mathrm{~m}$ (Fig. 3). The lake has an outlet at its western end and minor inlets in its northwestern end and is fed primarily by surface runoff (Nova Scotia Department of Fisheries, 1995). The lake is considered mesotrophic and the $\mathrm{pH}$ of the lake water is 6.8. The catchment relief is less than 25 $\mathrm{m}$ and the lakeside gradients are low to moderate. Three cores were collected from Canoran Lake. Sediment stratigraphy is best preserved in core \#2 which is $105 \mathrm{~cm}$ long.

The bottom part of the core (unit $1,105-95 \mathrm{~cm}$ ) is composed of a matrix-supported reddish brown diamicton with abundant pebbles (Fig. 2). L.O.I. for this unit is $2.5 \%$. Unit 1 grades into a fine-grained diamicton (unit 2, $95-82 \mathrm{~cm}$, L.O.I. 4\%) with abundant angular medium-grained sand to mediumgrained gravel clasts (16\%); this unit fines upward. Unit 3 $(82-68 \mathrm{~cm})$ consists of dark brown to blackish brown organicrich sediment that increases in L.O.I. up-core from 9 to $16 \%$. This sediment contains abundant fine- to coarse-grained angular sand clasts (8\%) and abundant pollen and diatom concentrations. The contact with underlying unit 2 is sharp. Unit 4 (68$66.5 \mathrm{~cm}$ ) consists of a reddish brown mud layer (L.O.I. 5\%) that contains abundant fine- to medium-grained angular sand clasts (10\%). The largest clast observed in thin section had a long axis length of $2.8 \mathrm{~mm}$. This sediment contains diatoms and rare pollen grains. The contact with underlying unit 3 is sharp but convoluted; the contact with overlying unit 5 is sharp. Unit 5 (66.5 cm - top of core) consists of dark brown to black organic-rich gyttja (L.O.I. 25\%); fine- to coarse-grained 

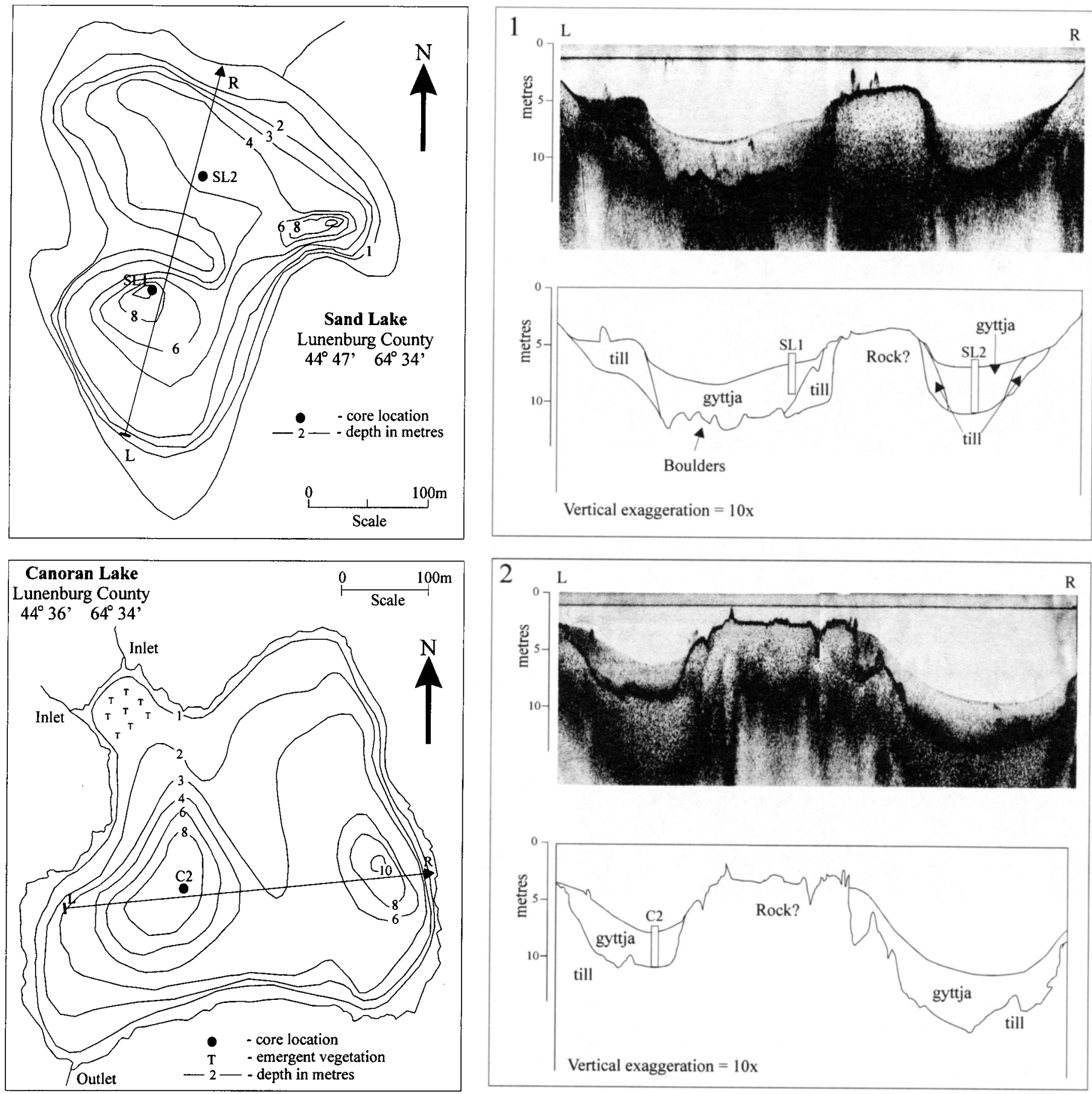

Fig. 3. Lake bathymetry and sonar profiles for Sand Lake and Canoran Lake, South Mountain. Both lakes contain at least one prominent sill leading to the development of local basins within each lake. Sub-bottom stratigraphy at both sites is complex. Variation of gyttja thickness is greatest at the basin margins and abrupt lateral transitions exist between the gyttja and till/rock. At both sites the maximum thickness of gyttja is about $4 \mathrm{~m}$ and is often not coincident with the deepest locations within the basin.

angular sand clasts were noted but became increasingly rare up-core. This unit contains ample rootlets and, in general, exhibits an increase in macrofossil content up-core. Volumetric grain size distribution in the clastic portion of this core $(0.016-630 \mu \mathrm{m})$ is similar to that observed in the Sand Lake core. Sand-sized clasts are most numerous in units $3(53 \%)$ and $5(17 \%)$, with lower concentrations in units $2(1 \%)$ and 4 (8\%).

\section{INTERPRETATION}

\section{North Mountain sites}

The sediments in both North Mountain sites record regional deglaciation and establishment of productivity within the catchment and the lake basin. The basal diamicton is interpreted to be the regional basal till. At both sites the till is 


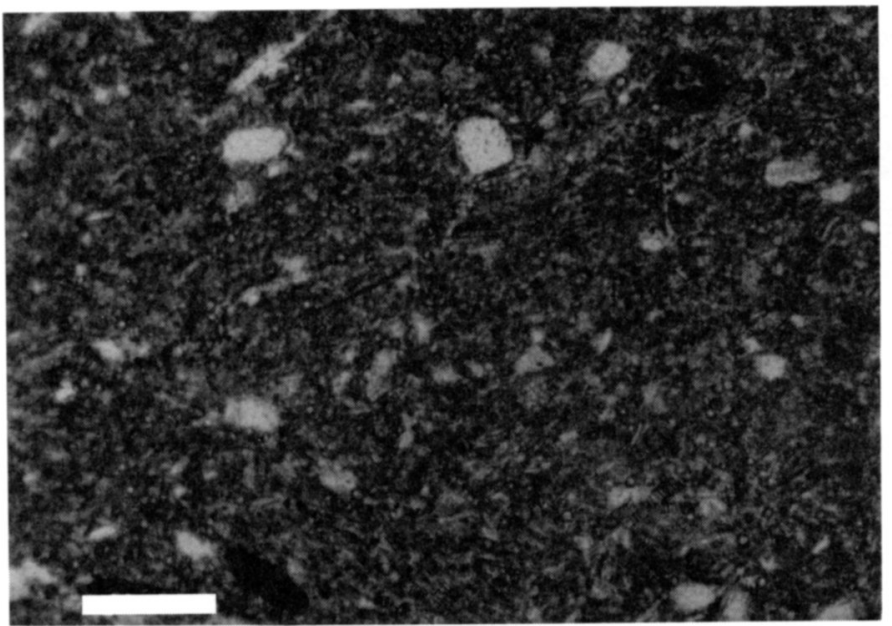

$4 \mathrm{a}$

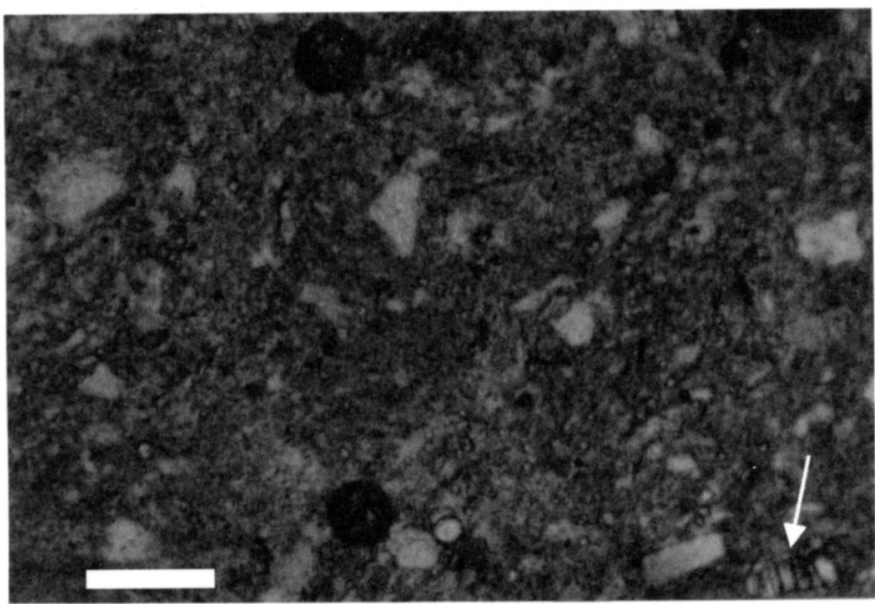

$4 \mathrm{~b}$

Fig. 4. Photographs of thin sections of YDimh $(70 \mathrm{~cm})$ and post Younger Dryas $(65 \mathrm{~cm}$ ) sediment from the Sand lake core (scale bar represents $0.25 \mathrm{~mm}$ ). Note the similarity in grain size of sand clasts between the two samples. Arrow points to diatom.

overlain by inorganic sediment. At Youngs Lake, unit 2a may represent glacio-fluvial (gravel lenses) or ice proximal (diamicton lens) deposition as glaciers receded from the site. Unit 2 is present in both cores and is probably sediment deposited as the catchment and basin stabilized following deglaciation (Dearing and Foster, 1991). The abrupt transition between unit 2 and unit 3 (gyttja) is an indication that both aquatic and terrestrial vegetation became established quickly once the site stabilized and increased productivity and reduced sedimentation rates prevailed. The sporadic angular fine-grained clasts observed in unit 3 were most likely transferred to the lake basin by eolian processes; their low concentration at the base of unit 3 is an indication that the local landscape stabilized quickly following deglaciation. The AMS radiocarbon age of $11760 \pm$

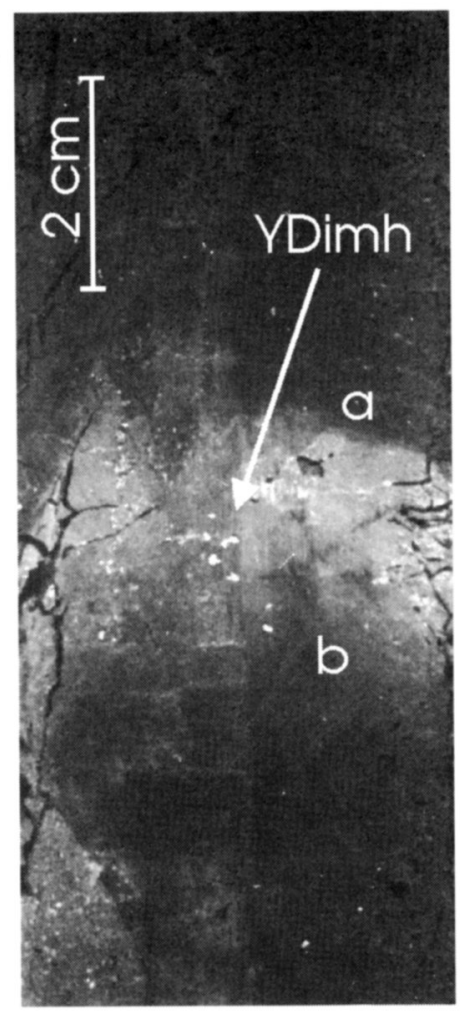

Fig. 5. Enhanced image of the Younger Dryas inorganic marker horizon (YDimh) from the Sand Lake core \#3. The upper contact (a) is sharp and the lower contact (b) is convolute, most likely a result of sediment mixing. Note the distinct colour change between the YDimh and the surrounding sediments.

240 B.P. obtained near the base of unit 3 in the Sandy Lake core is an indication that the site was deglaciated well in advance of Younger Dryas cooling. The lack of a strong mineral oscillation at either site is an indication that basin and catchment sediment transfer rates and intrabasin productivity varied little once the site became ice-free. The beta decay radiocarbon age obtained on a bulk sediment sample near the unit 2-3 contact in the Sandy Lake core \#3 (7330 \pm 200 B.P., Table 1 ) is in conflict with the AMS date obtained on core \#2. This anomolously young date may be a consequence of contamination by young carbon. However, this date could also be the consequence of natural sediment mixing or slumping within the lake basin. Complex sub-bottom stratigraphy leading to variability in the thickness of gyttja and sharp transitions between gyttja and pre-Holocene sediment is evident at the Sandy Lake site, and core \#3 was located near such a transition.

\section{South Mountain sites}

In both the Sand Lake and the Canoran Lake core, units 1,2 and 3 represent the transition from glacial conditions (unit 1; till) to the initial development of a lake basin (unit 2, fine diamicton) to the development of both stabilization and productivity within the lake basin and the catchment (unit 3, sandy gyttja). The sediments in unit 2 (angular gravel clasts suspended in a very fine-grained matrix) were deposited dur- 


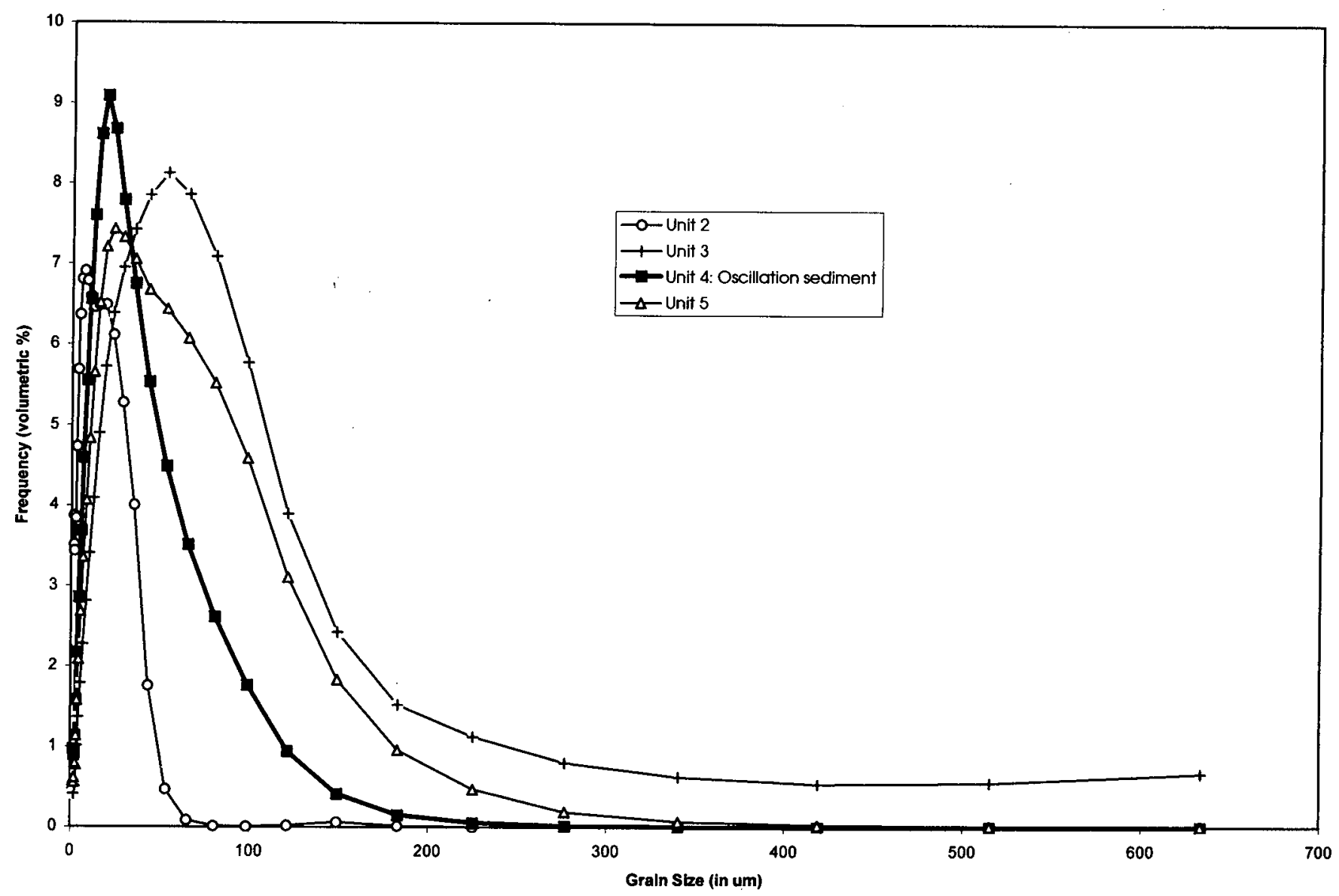

Fig. 6. Grain size analysis of units $2,3,4$, and 5 from the Sand Lake core. The size range analyzed was from 0 to $630 \mu \mathrm{m}$ and data is presented in volumetric percentage. Note that the pre-oscillation and post-oscillation units ( 3 and 5 , respectively) have greater volumes of sand-sized (50-630 $\mu \mathrm{m}$ ) sediment than either the postglacial sediment (unit 2) or the YDimh (unit 4).

ing deglaciation by sediment gravity flow as the basin developed. Similar sediments were observed by Stea and Mott (1993) in cores obtained throughout Nova Scotia. The relatively low L.O.I. values and the abundance of coarse-grained angular clasts in unit 3 are an indication that the landscape was not fully stabilized. Some of the coarser sediment may have been transferred to the lake basin by meltwater density currents (Smith and Ashley, 1985). It is equally likely that eolian processes were responsible for transporting the medium-grained sand to fine-grained gravel clasts observed in units 3,4 , and the lower portion of unit 5 onto the lake ice (Barndorff-Neilsen and Willets, 1991).

Unit 4 (silt with gyttja) is interpreted to be the YDimh. The sharp contacts with the bounding units $(3,5)$ is an indication that productivity and/or sediment influx mechanisms changed rapidly. The differences in coarse clastic concentrations between units 2 and 4 suggest that different processes (or a change in the duration or strength of the process) were responsible for the deposition of each unit. The limited thickness, fine-grained skew, and lack of gravel clasts in unit 4 is an indication that intense erosion of the catchment in response to regional cooling was unlikely.

The principal differences between units 3,4 , and 5 are the change in the relative volume of the organic component (as reflected by the L.O.I. data; Fig. 2) and the variability in the frequency distribution of the clastic component in each unit
(Fig. 6). At the Sand Lake site, the YDimh (unit 4) consists of an elevated volume (86\%) of silt and clay-sized sediment (as a function of total inorganic sediment) relative to units $3(60 \%)$ and $5(70 \%)$. If the decrease in L.O.I. observed for the YDimh is a function of decreased productivity (given constant sediment influx) the frequency distribution of the clastic portion of the lake sediment should remain relatively constant across boundaries. However, this was not the case (Fig. 6). Conversely, an increase in sediment influx (with constant productivity) should produce increased sedimentation rates and, possibly, the deposition of coarser sediment if the sediment transfer mechanisms became more robust, but these characteristics were not observed. These observations indicate that a variety of mechanisms were responsible for the deposition of unit 4. Changes in both productivity and the nature of sediment transfer processes are indicated and the relative importance of each will be discussed below. Unit 5 represents a return to organic productivity as the dominant sedimentation mechanism within the lake basin. The decrease in sand content up-core in unit 5 is an indication that eolian and/or density current sediment transfer rates decreased, probably a consequence of landscape stabilization.

The presence of gyttja below the YDimh is an indication that both sites were deglaciated well in advance of Younger Dryas cooling. The AMS radiocarbon age obtained on the Sand Lake core is consistent with other ages obtained for the 
termination of the Younger Dryas chron (Stea and Mott, 1998). As with the Sandy Lake site (North Mountain), the anomalously young beta decay age may be a consequence of introduced young carbon but might also be a result of syndepositional sediment mixing. The lateral variability in sediment type and the steep, sharp contacts at the core site may indicate an unstable depositional environment in which sediment redistribution could have occurred (Fig. 3).

\section{Discussion}

\section{Deglaciation}

The basal date obtained for the Sandy Lake (North Mountain) core indicates that the site was deglaciated prior to about $11.7 \mathrm{ka}$. Work by Stea and Mott (1998) on other North Mountain lakes has yielded similar dates for deglaciation. Resolution of the timing of deglaciation of the South Mountain is more problematic, as many of the lakes cored contain insufficient macrofossil remains and organic carbon to produce wellconstrained dates. The date of Railton (1973) for the base of the Canoran Lake core (Table $1,11760 \pm 160$ years B.P.) is an exception and indicates that the eastern edge of the South Mountain was deglaciated at about the same time as the North Mountain.

The Sand Lake site was chosen for this study in part because a basal date obtained from this site could constrain deglaciation of western Nova Scotia. The site is situated at the apex of the South Mountain, has the highest measured residual snow cover in western Nova Scotia (Stea et al., 1992) and would be the most likely location for late-glacial ice (Stea and Mott, 1989). Unfortunately, a lack of organic material at the base of the Sand Lake cores precluded dating the unit 23 boundary. However, Stea and Mott (1998) found that regression analysis of the pre-YD portion of cores indicates that fairly consistent sedimentation rates of about $0.014 \mathrm{~cm} /$ $\mathrm{yr}$ were probable at a wide variety of lake sites in mainland Nova Scotia. Applying this sedimentation rate to the Sand Lake core would result in the base of unit 3 being about 850 years older that the beginning of the YD, or about $11,650 \mathrm{ka}$. This date appears to be reasonable and would suggest that the site was deglaciated well in advance of Younger Dryas cooling. The fine-grained nature of the YDimh and presence of diatoms and pollen in units 3 and 4 are an indication that the persistence of permanent ice or snow cover during the Allerod was unlikely at the Sand Lake site.

\section{Environmental response to the YD event}

An understanding of the processes that led to the development of the YDimh is essential to understanding the geomorphic response to abrupt climate change. The mineral oscillation that is evident in many lake cores must fundamentally be a product of an increase in clastic sediment influx and/or a decrease in organic sediment influx/production. Most studies of the YDimh invoke catchment (as opposed to intrabasin) sediment transport processes to explain the increased mineral content. Pollen studies have indicated that abrupt cooling led to a change from shrub-tundra to herb- tundra vegetation during the Younger Dryas (Mayle and Cwynar, 1995). Mott (1994) demonstrated that the cooling was most likely accompanied by an increase in moisture. Landscape destabilization and increased meltwater/runoff would be a natural consequence of these conditions and has been invoked especially at sites where relatively thick, coarse clastic layers were observed (Mott et al., 1986; Beierle et al., 1997; Menounos and Reasoner, 1997; Stea and Mott, 1998).

The YDimh in both South Mountain lakes is about $2 \mathrm{~cm}$ thick. This value varies significantly from YDimh thicknesses obtained by Stea and Mott (1998) in western Nova Scotia. This difference may be due, in part, to the dynamic stratigraphy observed within these lake basins (Fig. 3). For this study, cores were obtained in the deepest portions of the basins where gyttja thicknesses are typically less than at other sites within the basin (Fig. 3). It is unlikely that sediment was lost during coring as the overall stratigraphy obtained in Canoran Lake (this study) is similar to that obtained by Stea and Mott (1998). As well, the total length of the cores obtained is in agreement with the sonar profiles.

If the average late-glacial sedimentation rates $(0.014 \mathrm{~cm} /$ yr) proposed for glaciated basins by Stea and Mott (1998) are applied, the YDimh at both Canaoran Lake and Sand Lake would represent about $\mathbf{1 5 0}$ years of sediment deposition. If increased clastic sedimentation rates are assumed, the YDimh would have been deposited in much less time. It is unlikely then that the YDimh is a product of a period of increased and sustained clastic sediment influx. The limited thickness and fine-grained nature of the YDimh might be expected, as the gradient and catchment area required to transfer sediment efficiently were not present at either site. Influx by sedimentladen meltwater streams is unlikely and would require that a positive relief meltwater source (either aufeis or glacial ice) be located nearby. The lack of variability in the maximum sediment grain size in the late-glacial portion of the cores suggests that sediment transfer processes were operating at the same energy levels but different rates. It seems unlikely then that the YDimh was the product of a dynamic influx of clastic sediment into the lake basin.

A change in clastic sediment supply could be accomplished by a variety of intrabasinal processes. Walker $e t$ al. (1991) noted that changes in chironomid populations that occurred during the Younger Dryas may have been produced by lake deepening. Lake-level change, accomplished primarily by a change in precipitation, and the focussing of wave energy on an unstable shoreline has been noted to result in a subtle increase in sediment transfer basinward in small lakes (Dearing and Foster, 1991). The resultant sediment oscillation commonly exhibits an increase in silt and clay (as opposed to sand) with respect to bounding sediment (Dearing and Foster, 1991) a characteristic that was also noted in unit 4 (Fig. 6) at both South Mountain sites.

A reduction in both allochthonous organic/clastic sediment influx and organic productivity within the lake basin is an alternative means of producing a mineral horizon. Scavia et al (1986) and Itkonen and Salonen (1994) have noted that increased lake-ice cover can dramatically affect nutrient availability, and consequently productivity, within lake basins. Levesque et al. (1997) noted that lake surface temperatures in 
New Brunswick decreased by 6 to $10^{\circ}$ during the Younger Dryas, a condition that could have resulted in increased lakeice cover (Cole, 1994). Rawlence and Senior (1988) and Rawlence (1988) indicated that perennial ice cover may have existed on Little Lake in New Brunswick during the Younger Dryas with only partial summer melting. It is evident from these studies that Younger Dryas cooling had the potential to produce both increased lake-ice cover and resultant productivity changes in susceptible lakes.

The lakes in this study would be susceptible to air temperature change as they are shallow and have low thermal inertia (a function of lake depth and morphology); increased ice cover might be expected in response to regional cooling. Under these conditions, both intrabasin productivity and the rate of transfer of allochthonous organic material and clastic sediment into the lake basin might decline. The sharp contacts between unit 4 (YDimh) and the bounding sediment (units 3 and 5, Fig. 5) may be an indication that productivity changed rapidly in response to climate change, a likely scenario given the low thermal inertia of the lakes. It is unlikely that this contact is solely a result of changes in clastic sediment influx, as the response of vegetation to climate change (and the resultant landscape destabilization) in low relief areas is gradual (Hare, 1976).

\section{Distribution of YDimh in western Nova Scotia}

The sporadic distribution of the Younger Dryas mineral oscillation (either as L.O.I./T.O.C. spike or as the YDimh) in western Nova Scotia is problematic. Mineral oscillations would be most common at sites that had large catchment, high gradient, and proximity to a meltwater source, and were located in a geomorphologically sensitive setting (recently deglaciated or sparsely vegetated). Few lake sites in western Nova Scotia are likely to have exhibited many of these characteristics. However, at some sites open vegetation stands that may have persisted through the Allerod would have been more susceptible to thinning during Younger Dryas cooling. Under these conditions both eolian and alluvial sediment transfer rates would have increased. These sites may have also been more susceptible to intrabasin productivity shifts. The ameliorating affects of the coastal setting may have reduced the magnitude of Younger Dryas climate change. As well, sites that are spring fed may have been less susceptible to air-temperature change. The reduced concentration of sand-sized sediment in the late-glacial portion of North Mountain lake cores (in contrast to the South Mountain sites) may be an indication that the sites were relatively stable and that both alluvial and eolian sediment transfer processes were relatively subdued.

These observations cannot be used to characterize the geomorphic response to Younger Dryas climate change at all sites in western Nova Scotia, anomalous sites also exist. Stea and Mott (1998) noted that steep-sided kettle lakes such as Sandy Cove Lake (site 11, Fig. 1) commonly contain enhanced late-glacial sedimentation rates in comparison to glaciated basins (South Mountain sites, this study). Local landscape instability was probably a contributing factor. As well, the presence of YD-equivalent sand- and diamicton-covered terrestrial organic sites (Nictaux Falls, Blomidon; Fig. 2) indi- cates that at these moderate- to high-gradient sites dynamic sediment transfer occurred during this time (Mott and Stea, 1993). In the absence of Younger Dryas-equivalent glacial ice it is certainly possible that local snow or ice buildup may have provided conditions under which mass wasting or meltwater influx could have occurred at specific sites. However, the subtle and variable nature of the lacustrine response is an indication that high-energy sediment transfer processes were most likely localized occurrences.

This study was limited by the inability to definitively link the mineral oscillation to either a change in productivity or sediment influx. The precise dating required to determine lateglacial sedimentation rates was not possible. However, research by Rawlence (1988), Rawlence and Senior (1988), Smith (1995; personal communication, 1997) and others has shown that changes in diatom populations may be used to estimate productivity. Where the sedimentary expression of climate change is subtle these types of studies may be of great benefit. As well, little is known about late-glacial moisture gradients, an essential ingredient to understanding the geomorphic response to climate change. The degree of regional and local variance is less well understood. It is evident that more detailed understanding of the magnitude and duration of 10cal climate change would be required to more clearly define the geomorphic response to Younger Dryas climate change.

\section{SUMMARY}

Western Nova Scotia was free of glacial ice by 11,500 B.P. (in advance of Younger Dryas cooling). It is unlikely that subsequent Younger Dryas-equivalent glaciation occurred. The processes that resulted in the deposition of the lateglacial sediments (including the YDimh) are complex. Pollen records have shown that more open vegetation conditions existed during the Younger Dryas time (Mott et al., 1986). Thinning vegetation could have led to soil instability and an increase in influx of mineral sediment into lakes. However, it is unlikely that landscape instability alone led to the production of the YDimh at the South Mountain sites. The subtle expression of this unit is an indication that intrabasinal processes may have played an important role in the formation of the YDimh. Suppression of organic productivity may have been a contributing factor and was most likely a result of an increase in lake-ice cover. The sporadic distribution of the YDimh is an indication that local factors dominated its formation.

\section{ACKNOWLedgements}

Financial support was provided by grants from NSERC and Acadia University. Field assistance was provided by G. Woolaver and D. Osburn. Radiocarbon analyses were directed by R.P. Beukens at Isotrace Laboratories, Toronto, Canada, and $\mathrm{H}$. Krueger at Geochron Laboratories, Cambridge, Massachusetts, U.S.A. Grain size analysis was coordinated by Katarzyna Issmer at Adam Mickiewicza University, Quaternary Research Institute, Poland. Conversations with R. Stea and I. Itkonen and reviews by R. Mott and N. Catto added greatly to this paper. 
Barndorff-Neilsen, O. and Willetts, B.B. (eds.). 1991. Aeolian Grain Transport 1 -Mechanics. Springer-Verlag, Wein, New York, 181 p.

Beierle, B., Smith, D.G., and Krouse, H.R. 1997. Abrupt Climatic change at 10,000 B.P.: Evidence for an isochronous sedimentary marker bed in western Alberta Lakes. In Abstracts, Canadian Quaternary Association $8^{\text {th }}$ Biennial meeting, Montreal, May 22-25, 1997, p. 3.

Broster, B.E. and MacDougall, D.A. 1997. Paleoseismic implications of fluid-escape structures in raised deltas at Lower Five Islands - Economy Point, Nova Scotia. Atlantic Geology, 33, pp. 1-10.

Cole, G.A. 1994. Textbook of Limnology. Waveland Press, Inc. Prospect Heights, Illinois, 412 p.

Cwynar, L.C. and Levesque, A.J. 1995. Chironomid evidence for late-glacial climatic reversals in Maine. Quaternary Research, 43, pp. $405-413$.

Dearing, J.A. and Fostrr, I.D.L. 1991. Lake sediments and paleohydrology studies. In The Handbook of Paleoecology and Hydrology. Edited by B.E. Berglund. John Wiley and Sons, New York, 867 p.

Doner, L. 1995. Late-Pleistocene Environments in Maine: The Younger Dryas Dilemma. M.Sc. thesis, University of Maine, Orono, Maine, U.S.A.

Dorion, C. 1997. Middle to late Wisconsinan Glacial Chronology and Paleoenvironments along a transect from eastern Coastal Maine North to New Brunswick and Quebec. In Abstracts, Canadian Quaternary Association $8^{\text {th }}$ Biennial meeting, Montreal, May 22-25, 1997, pp. 19-20.

HARE, K.F. 1976. Late Pleistocene and Holocene climates: some persistent problems. Quaternary Research, 6, pp. 507-517.

ITKONEN, A. and SALONEN, V. 1994. The response of sedimentation in three varved lacustrine sequences to air temperature, precipitation and human impact. Journal of Paleolimnology, 11, pp. 323-332.

KING, L.H. 1993. Proposed Younger Dryas glaciation of the eastern Scotian Shelf. Canadian Journal of Earth Science, 31, pp. 401-417. 1996. Late Wisconsinan ice retreat from the Scotian Shelf. GSA Bulletin, 108, pp. 1056-1067.

Levesque, A.J., Cwynar, L.C., and Walker, I.R. 1997. Exceptionally steep north-south gradients in lake temperatures during the last deglaciation. Nature, 385, pp. 423-426.

Mayle, F.E. and Cwynar, L.C. 1995. Multi-Proxy Data for the Younger Dryas in Atlantic Canada. Quaternary Science Reviews, 14, pp. 813-821.

Menounos, B. and Reasoner, M. 1997. Evidence for Cirque Glaciation in the Colorado Front Range during the Younger Dryas Chronozone. Quaternary Research, 48, pp. 38-47.

Miller, R.F. 1996. Late-Glacial (Allerod - Younger Dryas) Coleoptera from central Cape Breton Island, Nova Scotia, Canada. Canadian Journal of Earth Science, 34, pp. 247-259.

Motr, R.J. 1985. Late-Glacial climate Change in the Maritime Provinces. In Climate change in Canada 5: Critical Periods in the Quaternary Climatic History of North America. Edited by C.R. Harington. Syllogeus, No. 55, pp. 281-300.

-.- 1994. Wisconsinan Late-glacial environmental change in Nova Scotia: a regional synthesis. Journal of Quaternary Science, 9, pp. 155-60.

Mott, R.J. and SteA, R.R. 1993. Late Glacial (Allerod/Younger Dryas) Buried Organic Deposits, Nova Scotia, Canada. Quaternary Science Reviews, 12, pp. 645-657.
Mott, R.J., Grant, D.G., SteA, R.R., and Occhietti, S. 1986. Late Glacial climatic oscillation in Atlantic Canada equivalent to the Allerod/Younger Dryas event. Nature, 323, pp. 247-250.

Nova Scotia Department of Fisheries. 1995. Lake Information Sheets (Sandy Lake, Youngs Lake, Canoran Lake, Sand Lake, Nova Scotia). Nova Scotia Department of Fisheries, P.O. Box 700 , Pictou, Nova Scotia, B0K $1 \mathrm{HO}$.

Rallton, J.B. 1973. Vegetational and climate history of western Nova Scotia in relation to a South Mountain ice cap. Ph.D. thesis, Dalhousie University, Halifax, Nova Scotia, 146 p.

RAWLENCE, D.J. 1988. The post-glacial diatom history of Splan Lake, New Brunswick. 1988. Journal of Paleolimnology, 1, pp. 51-60.

Rawlence, D.J. and Senior, A. (1988). A late Glacial diatom and pigment history of Little Lake, New Brunswick with particular reference to the Younger Dryas climatic Oscillation. Journal of Paleolimnology, 1, pp. 163-177.

Reasoner, M.A. 1993. Equipment and procedure improvements for a lightweight, inexpensive percussion core sampling system. Journal of Paleoclimatology, 8, pp. 273-281.

Scavia, D., Fahnenstiel, G.L., Evans, M.S., Jude, D.J., and Lehman, J.T. 1986. Influence of Salmonine Predation and Weather on Long-Term Water Quality Trends in Lake Michigan. Canadian Journal of Fish Aquatic Sciences, 43, pp. 435-443.

SMIT, I.R. 1995. Holocene paleolimnoligical records from the Hazen Plateau, northern Ellesmere Island. 2nd Annual PALE research meeting, Seattle, Washington, Abstracts Volume, \#39.

SMITH, N.D. and AshleY, G. 1985. Proglacial Lacustrine Environments. In Glacial Sedimentary Environments. Edited by G. Ashley, J. Shaw and N. Smith, SEPM Short Course No. 16, 246 p.

Stea, R.R. and Mott, R.J. 1998. Deglaciation of Nova Scotia: Stratigraphy and Chronology of Lake Sediment Cores and Buried Peat Sections. Geographie Physique et Quaternaire, 52:1, pp. 3-21.

-.--- 1989. Deglaciation Environments and evidence for glaciers of Younger Dryas age in Nova Scotia, Canada. Boreas, 18, pp. 169-187.

Stea, R.R., Boyd, R., Costello, O., Fader, G.B.J., and Scott, D.B. 1996. Deglaciation of the inner Scotian Shelf, Nova Scotia: correlation of terrestrial and marine glacial events. In Late Quaternary Palaeoceanography of the North Atlantic Margins. Edited by J.T. Andrews, W.E.N. Austin, H. Bergsten and A.E. Jennings. Geological Society Special Publications, No. 111, pp. 77-101.

Stea, R.R., Forbes, D.L., and Mott, R.J. 1992. Quaternary Geology and Coastal Evolution of Nova Scotia. Geological Association of Canada/Mineralogical Association of Canada, Joint Annual Meeting, Wolfville 1992, Field Excursion A-6, Guidebook, $125 \mathrm{p}$.

WALKER, I.R., MOTT, R.J., and SMOL, J.P. 1991. Allerod-Younger Dryas Lake Temperature from midge fossils in Atlantic Canada. Science, 253, pp. 1010-1012.

Wilson, S.E., WAlker, I.R., Mott, R.J., and Smol, J.P. 1992. Climatic and limnological changes associated with the Younger Dryas in Atlantic Canada. Climate Dynamics, 8, pp. 177187. 